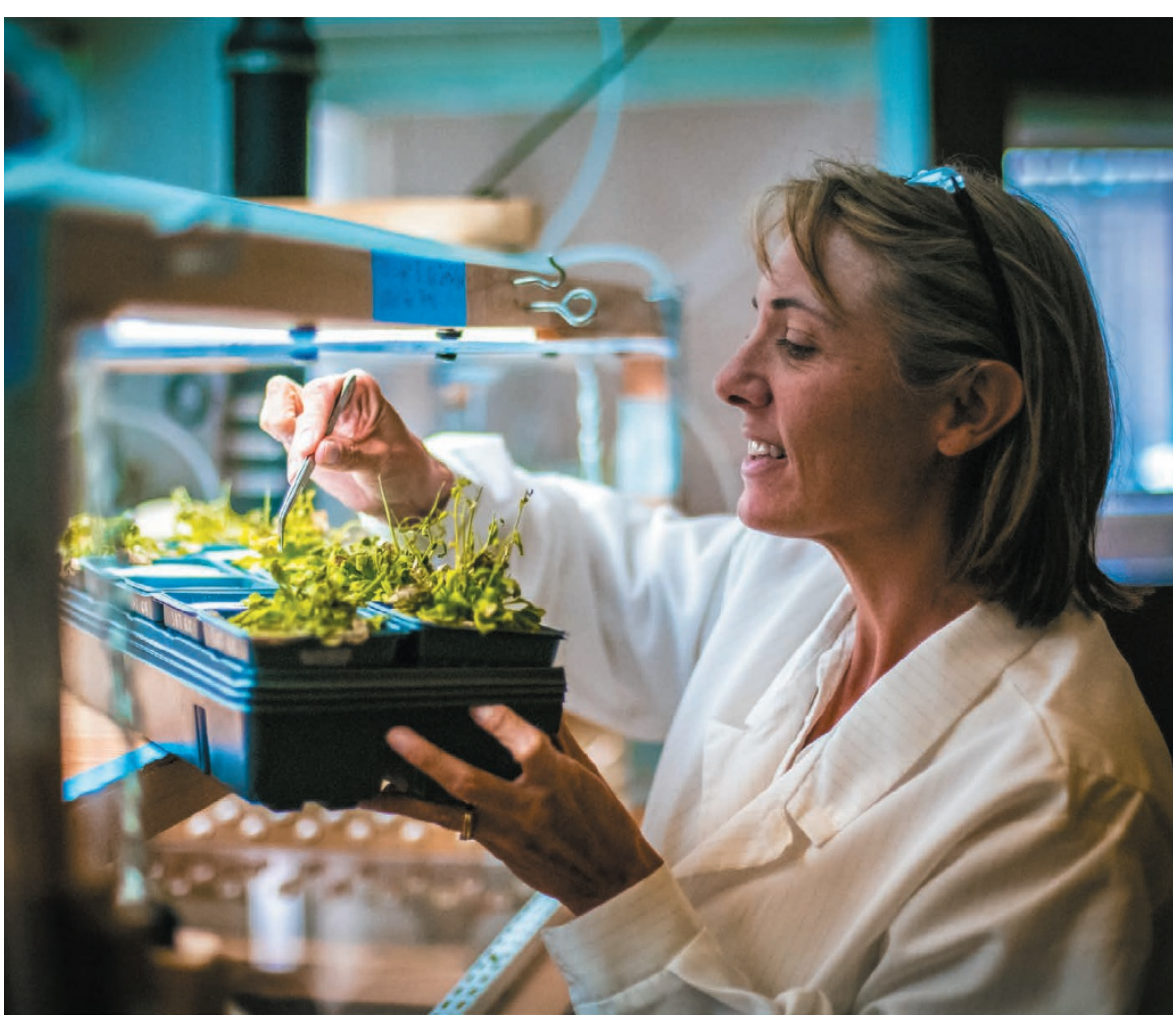

Hope Jahren has been outspoken about the rights of women in academia.

\title{
AUTOBIOGRAPHY
}

\section{A lab of one's own}

\section{Jennifer Rohn delights in the discovery-laden memoir of palaeobiologist Hope Jahren's life scientific.}

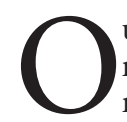
urs is a profession still largely unfamiliar in popular culture. Scientists' memoirs are scarce, and even rarer are those by women, who are still finding their way in a male-dominated environment.

Hope Jahren is the voice that science has been waiting for. Her autobiography, $L a b$ Girl, is a tell-all that demystifies a research career even as it reveals its - at times overpowering - strangeness. Jahren, a palaeobiologist at the University of Hawaii at Manoa, writes a popular candid blog (www. hopejahrensurecanwrite.com), mostly about the plight of women in research academia. But Lab Girl is much more. From childhood origins as a loner hiding in the classroom lab of her science-teacher father, through a 20 -year career, Jahren's voice is clear, compelling and uncompromisingly honest.

Jahren studies the chemical composition of both modern and fossilized life to understand Earth's changing environment. Plants are central to this story, and twining through her account like tenacious ivy are weird and wonderful strategies that they deploy to battle a hostile world. Jahren's first 'eureka moment' is discovering that the hackberry tree (Celtis occidentalis) toughens its seeds by coalescing minerals into opal. We learn how trees survive winters at $-40^{\circ} \mathrm{C}$ : their cells secrete pure water while concentrating sugars and proteins as a syrupy

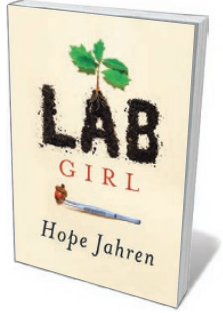

Lab Girl

HOPE JAHREN Knopf: 2016 antifreeze, so that ice crystals do not form inside the cell. And when it comes to their progeny, the odds are vanishingly small that any one seed will reach adulthood. Plant development, from tentative rootlets to mature fruit, with plenty of knots in between, becomes a metaphor for Jahren's own progress in the challenging landscape of academia.

Much of Jahren's research takes place outdoors, and it has ranged all over the globe. Although her staple technique is state-ofthe-art isotope analysis, her investigations are guided by careful observation of nature in situ. She's the type of scientist who cheerfully spends three seasons drilling 30 metres through Arctic turf, one painstaking centimetre at a time. Even the most casual obser-vation, such as how a species of moss springs back when she removes her foot, can suggest a hypothesis. Between sessions of hard graft, her lab group takes road trips to see bizarre attractions, or attempts elaborate campfire cuisine.

Amid descriptions of Jahren's work, uncomfortable secrets of science are laid bare. Jahren breezily reveals how scientists sometimes work on tangents not mentioned in their grants. She confesses that writing papers can be an exercise in narrative retrofitting, a "size-zero mannequin designed to showcase the glory of a dress that would be much less perfect on any real person". The sterile language of papers also obliterates the human drama, such as when data must be reprocessed after a student quits, not wanting to consign herself to a life like Jahren's.

Above all, Jahren exposes the 24-7 lab culture familiar to many academic researchers. When she's desperate to get the papers and grants needed to keep open her fledgling lab at the Georgia Institute of Technology in Atlanta, Jahren and her technician and friend, Bill, go days at a time without eating or sleeping properly. At a seminar, Jahren gnaws on a dog biscuit to prevent her stomach from rumbling. In another account, a night janitor stumbles on her and wisely observes: "However much you love your job, it ain't gonna love you back." Meanwhile, the long-suffering Bill sleeps rough in a van because his meagre salary cannot stretch to renting a room.

Jahren also pulls no punches on the stark realities of being a woman in science, which won't come as a surprise to many. She defines sexism as "the cumulative weight of constantly being told that you can't possibly be what you are". At one conference, she stands alone, "trapped with pasty middle-aged men who regarded [her] as they would a mangy stray". She overhears male colleagues speculating about her sexual orientation and waistline, and has to endure colleagues' discomfort during her pregnancy. This is not a how-to manual, but young scientists of either gender could learn a lot simply from Jahren's perseverance.

Lab Girl is funny, full of joyous moments and often sad. But despite all the hardship, there is clearly nowhere else that Jahren would rather be. "My lab," she writes, "is a place where I can be the child I still am," a home where "the lights are always on", a church "because it is where I figure out what I believe". -

Jennifer Rohn leads a cell-biology group at University College London. Her most recent novel is The Honest Look. e-mail:jenny@lablit.com 